\title{
THE PRINCIPLE OF UNIVERSALITY
}

\section{Dr. Lech Gardocki \\ Warsaw University}

1. The principle of universality belongs to the part of international criminal law which is sometimes called criminal law conflict rules. The reason for including such provisions determining the applicability of a given criminal law, even if they are placed in an internal legal system, in the international criminal law is that they concern criminal matters containing some foreign element.

These provisions have a double meaning. They establish both the scope of applicability of the substantive criminal law and the range of the jurisdiction of courts of a given state. The two sides of the rules of competence are closely connected with each other. There exists nowadays a strict inseparability of the applicability of substantive criminal law and the jurisdiction. As is well known, the situation in civil matters is quite different. In civil cases, the application by courts of foreign substantive civil law is possible. Criminal courts, however, do not apply foreign criminal law. ${ }^{1}$

For this reason, the criminal laws of respective states do not determine separately the range of jurisdiction of their courts and the scope of application of the substantive law provisions, but regulate only one of these questions. In continental law, criminal codes usually determine the scope of applicability of criminal law by establishing such principles as the principle of territoriality, passive and active personality principle, protective principle and principle of universality.

But there are some exceptions. For instance, in the French legal system, the code of criminal procedure establishes only the scope of jurisdiction of French criminal courts.

1 Some criminal codes admit the possibility of "taking into consideration" foreign criminal law as "lex mitior". But this cannot be called application of foreign law since it is never an independent legal basis of conviction. 
The choice of the criminal code or of the code of criminal procedure and, in consequence, the regulation, either of the applicability of criminal law or of the jurisdiction of criminal courts, is practically of no importance. In the states whose law points out only the jurisdiction of criminal courts, it determines at the same time the scope of their criminal law, since those courts cannot apply foreign criminal law provisions. On the other hand, in the states where law determines only the applicability of their criminal law, it determines automatically also the jurisdiction of their criminal courts, since no other courts could apply this law.

These two sides of the law of competence could be separated if the possibility were created in future of the application of foreign substantive criminal law. At present, however, such a perspective seems not to be very near.

The double character of the rules of competence in criminal law leads to the Latin maxim expressed by Zlataric", "cuius lex criminalis eius iurisdictio". The same author also states rightly that this maxim can be reversed as well to read, "cuius iurisdictio eius lex criminalis".

The preliminary remarks above concerning the legal character of the rules of competence in criminal law mean that whenever in this report the principle of territoriality, protective principle etc. are mentioned, both aspects are meant, the jurisdictional and that of substantive criminal law.

2. The establishment of rules of jurisdiction and of the application of substantive criminal law belongs to the sovereign rights of every independent state. The limitation of the discretionary power of a state in this respect can result from the public international law. If such a limitation does not exist, the state is free to determine an optionally broad range of its own criminal law and the jurisdiction of its courts. Hence, the state needs no particular authorization resulting from public international law. No permissive rule of this law is required here.

The international criminal law conventions do contain provisions concerning jurisdiction, but their aim is not to create additional rights for the signatories. On the contrary, their aim is always to oblige the signatories to establish such jurisdiction in order to avoid possible jurisdiction lacunae.

The principle of freedom of determining jurisdiction in criminal matters seems to be recognized nowadays, and, which is very important, it is

2 B. Zlataric: Medunarodno krivicno pravo, Zagreb 1979, p. 69. 
constantly confirmed by the uniform practice of states. But at the end of the 19th century the United States still tried to contest jurisdiction of a Mexican court in the Cutting case ${ }^{3}$ concerning an American subject who had committed an offence in the USA against a Mexican citizen. In this case, the Mexican court based its jurisdiction on the principle of passive personality.

The most important precedent in this field is the decision of the Permanent Court of International Justice in the Lotus case. ${ }^{4}$ A French ship "Lotus" had a collision on the high sea with a Turkish ship which caused the death of a Turkish sailor. The Turkish authorities arrested a French officer during the stay of the ship in Istanbul and brought him before a Turkish criminal court.

In this case, the French government contested the jurisdiction of the Turkish court based on the passive personality principle. The Permanent Court of International Justice stated in its judgement that no provision of international law forbade the Turkish legislator to establish jurisdiction of Turkish courts in such a case.

The decision of the PCIJ had a double importance. First, it decided a specific question in the field of the maritime law, recognizing the existence of the jurisdiction of Turkish courts although the collision took place on the high sea. Second, it formulated indirectly a certain general principle, according to which every state is free to determine its criminal law competence unless a binding norm of public international law limits this freedom. ${ }^{5}$

As to the first question, it should be mentioned that the subsequent development of maritime law took an entirely different direction. The Geneva Convention of 1958 on the High Seas limited the states' liberty of determining jurisdiction. In the case of a collision of ships on the high sea, only the flag state or the state of the perpetrator's citizenship has jurisdiction over the case.

3 See, H. Donnedieu de Vabres: Les principes modernes du droit pénal international, Paris 1928, p. 108.

4 Permanent Court of International Justice, series A (Collection of Judgements), No 10 (1927).

5 According to Sundberg, "The Lotus case only crowned a general process towards more extraterritorial application of the criminal law". See, J. Sundberg: Piracy and Terrorism (in:) Bassiouni \& Nanda: A Treatise on International Criminal Law, Vol. I, p. 470-471. 
On the other hand, the general rule of freedom of establishing jurisdiction, established at this occasion, still remains valid. As I have mentioned above, this rule is constantly confirmed by the common practice of states. Creating provisions concerning jurisdiction, they do not look for any special authorization in public international law. Neither do they try to avoid concurrence with the jurisdiction of any other state. As a result of this approach, in criminal cases with a foreign element, we usually deal with the concurrence of criminal jurisdiction of two or more states. Very often there is concurrence of jurisdiction based on the principle of territoriality and jurisdiction of another state based on the active personality principle.

Concurrence of this kind is only a formal reflection of the fact that more than one state is interested in prosecuting the perpetrator. This situation can be considered as a favourable starting-point for international cooperation in criminal matters.

In the international criminal law literature, opinions can be found that formulate the principle of freedom of establishing jurisdiction in a more narrow manner. So for instance Jescheck states ${ }^{6}$ that "each state has full authority to determine the limits of its own criminal power, but as a constituent part of the international community of nations, each state in making the determination of its own criminal power must give due regard to the relevant international law rules, whether they are found in treaties, customary international law or in general legal provisions which are recognized by all civilised nations". Further, Jescheck states also that international law knows a general rule in this respect. In his opinion, "the most important of such generally recognized legal principles is that a state may not arbitrarily subject to its own criminal power acts which either ocurred abroad or were committed by a foreigner, unless there exists a meaningful point of relation which rationally connects the factual context of the act to the legitimate interests of the prosecuting state".

Also M. Cherif Bassiouni ${ }^{7}$ states that a specific principle of jurisdiction can be applied to a given situation, only if there exists a link between the state desiring to assert jurisdiction over the offence and the offence itself, the offender, or the victim.

6 See, H.-H. Jescheck: International Criminal Law: Its Object and Recent Development (in:) Bassiouni \& Nanda, op.cit., Vol. I, p. 51.

7 See, M. Cherif Bassiouni: International Extradition and Public Order, 1974, p. 261. 
Oehler ${ }^{8}$ stresses the limitations of the freedom of establishing jurisdiction in criminal matters more decidedly. Also in respect to the principle of universality, he considers necessary the existence of an authorization resulting from an international treaty or customary international law. ${ }^{9}$ But at the same time, he points out many examples ${ }^{10}$ of the introduction by various states of the principle of universality into their own criminal laws, without looking for any international authorization.

In my opinion, it is undeniable that international law can limit the state's right to determine its own jurisdiction in criminal matters. Such limitations are however very rare in international conventions. The existence of such limitations in customary international law is doubtful and has not been proved as yet. In particular, I believe we cannot speak of the existence of such a general rule as mentioned by Jescheck and Bassiouni.

It is, of course, out of the question that every state while determining the range of its jurisdiction should always consider whether there exists a "meaningful point of relation" between the state and the offence or offender. A lack of such a link means only that the state determines an unnecessarily broad range of its jurisdiction; this does not mean, however, that its national law violates international law.

3. After the general remarks above relating to the principles of criminal law competence and principles of jurisdiction, I now come to specific problems connected with the principle of universality.

According to the principle of universality, the courts of a given state are competent, and its substantive criminal law is applicable, in the case of some offences, if the perpetrator finds himself within the territory of that state. This principle can also be formulated more broadly, namely, that the only criterion is the character of the offence committed, irrespective of the place where the perpetrator is. Such a broader formulation of the principle of universality can be found e.g. in the Geneva Convention of 1958 on the High Seas in relation to piracy (Art. 19). According to this provision, on the high sea or in another place beyond the power of any state, every state can seize the ship and punish pirates. Similarly broad formulations can be found in several internal criminal

${ }^{8}$ See, D. Oehler: Internationales Strafrecht, 1983, p. 124.

9 Op.cit., p. 538: "Nur das Völkergewohnheitsrecht z.B. für Piraterie oder Vertrage vermögen für bestimmte Taten den Täter also hostis humani generis zu qualifizieren und das Weltrechtspflegeprinzip für die Staaten zu eröffnen."

10 Op.cit., pp. 535-536. 
legislations. Thus the type of the offence committed and, if the principle is formulated less broadly, the place where the perpetrator is found ${ }^{11}$ are sufficient conditions for the application of the principle of universality.

The principle can be better characterized from the negative side. Thus the principle of universality is applicable irrespective of the place of commission, of the citizenship of the perpetrator, and of the punishability of the act on the territory where it has been committed.

As Donnedieu de Vabres mentioned in his book on international criminal law ${ }^{12}$, the principle of universality has a subsidiary character. According to Feller ${ }^{13}$, the jurisdiction is subsidiary in a double sense. First, the principle of universality is applicable if no other principle of jurisdiction can be applied. Second, the principle of universality is applicable only if the perpetrator has not yet been judged by the court of another state for the same offence. The first aspect of the subsidiarity of the principle needs no special justification. There exists undoubtedly some hiearchy of the jurisdiction principles. Those demanding less to be applied in a given case are placed in a lower position in that hierarchy. This is not without importance for determining which principle, known in a given criminal law, should be applied in a specific case, and also for deciding which state has a "better right" to prosecute the perpetrator. In both situations, the principle of universality is placed at the end of the list. For example, Bassiouni, in his Draft International Criminal Code, places the principle of universality at the end of the list, after the principle of territoriality, active and passive personality, and protective principles. ${ }^{14}$

This could also lead to another conclusion. Namely, since the principle of universality is the weakest one and should always give way to other principles, then perhaps extradition to another country should always have priority to prosecution based on universality. Such an opinion was

11 According to some authors, the decisive condition for applying the principle of universality is the fact that the alleged perpetrator was arrested on the territory of a given state. Actually, it is a simplification, since the arrest of the alleged perpetrator must be grounded on the prior existence of jurisdiction.

12 See, Donnedieu de Vabres: op.cit., p. 135.

13 See, S.Z. Feller: Jurisdiction over Offenses with Foreign Element (in:) Bassiouni \& Nanda, op.cit., Vol. II, p. 34.

14 Bassiouni: International Criminal Law. A Draft International Criminal Code, 1980, p. 145. 
firmly advocated by Donnedieu de Vabres ${ }^{15}$ who stated that extradition always has priority, because the only sense and raison d'être of the principle of universality consists in avoiding impunity of the perpetrator. ${ }^{16}$

On the other hand, Oehler ${ }^{17}$ argues convincingly that the application of the universality principle does not depend on the problem of extradition because the universal jurisdiction has a primary character and, unlike the representation principle, its reason is not to replace another state in punishing the perpetrator.

It should also be mentioned that several domestic criminal legislations containing this principle do not make it subsidiary in relation to extradition. This does not mean, of course, that extradition cannot be granted; it just has no priority over the principle of universality.

Instead, the principle of universality is certainly subsidiary in the sense that a conviction in another country for a given act excludes its application. Even if such subsidiarity is not explicitly prescribed in the text of the law, it should be considered as implied. Once the main justification of the principle is the violation of the interests of the world community, the duty to protect these interests can be fulfilled by any member of this community and need not be doubled.

In the Harvard Draft Convention on Jurisdiction with respect to crimes, the principle of universality has been defined in a differentiated way. In Art. 9 of the Draft, it is formulated very broadly in respect to piracy ("A state has jurisdiction with respect to any crime committed outside its territory by an alien which constitutes piracy by international law.")

In Art. 10 of the same Draft, also titled "Universality Principle", jurisdictional rules can be found with respect to other crimes. They contain, however, many additional conditions. First of all, the jurisdiction of a given state depends on the condition of criminality of the act in the state where it has been committed or in the native state of the perpetrator. Furthermore, the state is in the first place obliged to offer extradition to the country where the offence was committed.

15 Donnedieu de Vabres, op.cit., p. 160.

16 As he wrote, the principle of universality is applied "pour éviter, dans un interêt humaine, une impunité scandaleuse", op.cit., p. 135.

17 Oehler, op.cit., pp. 147 and 508. 
Oehler ${ }^{18}$, criticizing the Harvard Draft, remarks that here two different principles are not distinguished: the universality principle and the representation principle (the principle of vicarious jurisdiction). In his book, Oehler gives much attention to the question of differences between them..$^{19}$ In his opinion, the substantial difference is that the universality principle is grounded on the existence of a state's real interest in prosecuting the perpetrator for a given crime, while the representation principle is based on the abstract solidarity of states: in a specific case, an interest of another state is violated, and prosecution occurs in the substitution of that state, though its request for prosecution is not necessary. ${ }^{20}$ From a formal point of view, the difference between the two principles is that the application of the representation principle requires a fulfillment of some additional conditions. First of all, the act must be punishable in the place where it has been committed, and if the lex loci delicti is more lenient for the perpetrator, he has the right to take advantage of this.

Here, the subsidiarity of jurisdiction appears more distinctly than in the case of the universality principle. There is no doubt that a previous conviction in another country makes prosecution impossible. It is also beyond doubt that this principle is not applicable if extradition to the more competent state is possible.

It should also be mentioned that one of the conditions of the representation principle (though it is not always explicitly formulated in the legal provisions) is the presence of the perpetrator on the territory of a given state. One can hardly imagine an extradition request submitted in order to punish the perpetrator on the basis of the representation principle.

To recapitulate, it can be said that the differences between the universality principle and the representation principle concern the question of double criminality, subsidiarity, and the type of offences to which the principles relate. If the principle of universality is formulated broadly, as

20 As Oehler states (p. 145): "Ein Verfolgungsersuchen eines anderen Staates ist nicht notwendig ... Wäre ein Verfolgungsersuchen von seiten des Tatortsstaates ö.a. notwendig, würden grosse Lücken in der Strafverfolgung entstehen, weil sehr häufig dieses Ersuchen gar nicht gestellt wird."

On the other hand, Feller (op. cit., 36) is of the opinion that the representation principle "is involved - sometimes even in a formal sense - at the request of a foreign sovereign". 
e.g. in Art. 9 of the Harvard Draft, the difference concerns also the question of the perpetrator's presence on the territory of a given state.

All these differences seem to be sufficiently important arguments for the opinion that one should not bring these two principles together. Particularly, it is not advisable to call the representation principle a "limited principle of universality", for this could lead to terminological misunderstandings.

4. The origin of the principle of universality is usually linked with the crime of piracy. Donnedieu de Vabres wrote, however, that this principle was fragmentarily applied already in ancient times and in the Middle Ages in relation to some other serious crimes of a common character. In the Middle Ages, this practice was grounded on a theoretical construction according to which a criminal act travels with the offender ("l'action coupable voyage avec le delinquant"). It is very interesting that the need for the application of the universality principle appeared, similarly as in the case of piracy, in connection with the presence of some dangerous persons. As Donnedieu de Vabres wrote, in the criminal law of the medieval Italian towns the mere presence of some dangerous, unpunished criminals ("banniti, vagabondi, assasini”), causing anxiety, gave the reason to punish them for an offence committed elsewhere. ${ }^{21}$

A similar psychological mechanism created the practice of the application of the principle of universality in relation to the crime of piracy. By virtue of the customary international law, pirates, as hostes humani generis, were prosecuted by the authorities of every civilized state. The reason was that piracy was considered dangerous for the interests of the entire world community. Contemporarily, in the international criminal law literature, the application of the principle of universality is usually justified by the fact that the offences concerned are directed against the universal, commonly recognized and important values the protection of which is a common duty of all states of the world. Because of the specific character of these offences and their importance, it is necessary that all states establish their jurisdiction without putting any special preliminary conditions, in particular without demanding double criminality of the act committed, irrespective of the place of its commission and the perpetrator's citizenship.

21 Donnedieu de Vabres, op.cit., p. 135. 
This severe character of the principle of universality explains why only a few international conventions mention it expressly. Oehler ${ }^{22}$ quotes in this context: the International Convention for the Suppression of Counterfeiting Currency of 1929, the Geneva Convention on the High Seas of 1958 (piracy), the Convention for the Prevention and Suppression of the Crime of Apartheid of 1976, and the Geneva Conventions of 1949 (war crimes).

On the other hand, this principle appears much more often in domestic criminal law. Its range is rather broad in the criminal law of Hungary, Spain, FRG, Poland, Greece, GDR. More reserved in this respect are the criminal codes of Finland, Italy, Holland, France and Czechoslovakia.

It is not easy to explain why the principle of universality is more popular in domestic criminal laws than in international conventions. One cannot exclude, however, that this results from the resolutions of the First Conference of the Unification of the Criminal Law (Warsaw 1927) which recommended the application of this principle in relation to all crimes called "delicta iuris gentium" and contained a model provision concerning this question.

5. Since those days, opinions about the principle of universality have changed considerably. Nowadays, it is not accepted any more as the best rule for regulating the question of jurisdiction over delicta iuris gentium and is rather often criticized.

Dautricourt ${ }^{23}$ objects to this principle, stating that it "grants in fact a privilege to the offender or to the criminal in that he can choose the country and the authorities to which he surrenders". Oehler ${ }^{24}$ argues, comparing provisions in force in France and in the FRG, that the universality principle is almost superfluous and can be replaced by the representation principle with no detriment.

Lombois $^{25}$ is of the opinion that the principle of universality can be accepted only on the condition that the question of jurisdiction and the question of applicability of a criminal statute are separated from each other. He believes this principle to be appropriate only to decide on jurisdiction. Instead, the choice of the criminal statute should not be based on

22 Oehler, op.cit., pp. 520-521.

23 J. Dautricourt: The Concept of International Criminal Jurisdiction - Definition and Limitation of the Subject (in:) Bassiouni, Nanda, Vol. I, p. 642.

24 Oehler, op.cit., p. 543.

25 C. Lombois: Droit pénal international, 1971, p. 19. 
it as it leads to a purely accidental result, since the place of the apprehension of the alleged perpetrator is mostly accidental.

Wilkitzki26 remarks that there exists nowadays an international tendency to replace the principle of universality with the representation principle. The reason for this is the conviction that it is more advisable to establish one jurisdiction for international crimes and to avoid in this way a possible conflict between different jurisdictions.

The authors of the Dutch report for the XIV Congress of AIDP27 declare themselves decidedly against the principle of universality. They state that the Dutch legislator's reserve towards this principle has very good reasons. In their opinion, "the disadvantage of unlimited and uncritical acceptance of the principle of universal jurisdiction is that one is insufficiently aware of the question as to in which state prosecution should preferably take place. Such acceptance then increases the risk of double prosecution or punishment of the same person. Furthermore, the application of the principle of universal jurisdiction can lead to conflicts between states, especially in cases in which prosecution by a state availing itself of the principle of universality is not based on the impossibility of extraditing the probable perpetrator to the state more directly affected by the crime." ${ }^{28}$ In conclusion, they believe that the incorporation of the principle of universality in conventions should be avoided whenever possible.

Also di Bucci ${ }^{29}$ is rather sceptical about this principle because, in his opinion, it does not guarantee a trial before the most appropriate criminal court.

In my opinion, we experience a collision of two opposite tendencies in respect to the principle of universality. The origin and early history of this principle is marked by the intention to avoid a possible jurisdiction gap, to secure that at least one state will have jurisdiction over certain crimes.

26 P. Wilkitzki: Les Crimes Internationaux et le Droit Pénal Interne. Rapport par Peter Wilkitzki, p. 30.

27 A. Orie, C. Rüter, J. Schutte \& A. Swart: International Crimes and Domestic Criminal Law. Dutch Report, p. 21.

28 The rapporteurs gave an example of this situation. According to them, the prosecution in the FRG of some crimes committed in Holland, on the basis of the universal jurisdiction, sometimes leads to friction between the two countries.

29 Di Bucci (in:) G. Pisapia, M. Boscarelli, G. Uberti, N. Galantini \& V. Di Bucci: Les crimes internationaux et le droit pénal interne. Rapport di Centro Nazionale di prevenzione e difesa sociale, p. 29. 
Today, however, a greater and greater emphasis is laid on the necessity of limitation of jurisdiction in order to avoid jurisdiction conflicts.

In this situation, some compromise is necessary. In my view, a good solution would be to make universal jurisdiction subsidiary to extradition, if it is demanded by the state grounding its jurisdiction on the principle of territoriality, the passive or active personality, or the protective principle.

The problem remains, however, to what extent such a modified principle of universality should be promoted in relation to the delicta iuris gentium. Would it not be more advisable to replace it openly with the representation principle? Is the universality principle a disappearing one? Has it no future?

The enthusiastic opinion about the principle of universality, common in the past, is undoubtedly less and less supported nowadays. In particular, it is difficult to support the opinion that delicta iuris gentium should be prosecuted irrespective of their punishability in the place where they were committed. The inclusion of some crimes in the category of international crimes sensu largo (delicta iuris gentium, conventional crimes) is based on the need for international cooperation in prosecuting them. It need not imply, however, that the condition of double criminality of the act should be eliminated. Actually, such need exists only in respect to the crimes usually committed in a place not subordinated to any state power, especially on the high sea. From this point of view, piracy, offences against submarine cables, and sea pollution can be mentioned. Further, such a need exists if the crimes concerned are partly or fully tolerated by the legal system in force in the place of their commission. Oehler ${ }^{30}$ gives in this context the example of war crimes. The jurisdiction over them cannot, in his opinion, depend on the criminal law of the state where they were committed, since this law can sometimes give the appearance of legality to acts violating the law of warfare, e.g. by formulating some justification.

I believe this argument can be referred to also in relation to some other international crimes sensu stricto (as e.g. genocide or crimes against the peace) and to the crime of apartheid.

In conclusion, the principle of universality is not likely to be applied to all international crimes in the future. Nor is it likely to disappear completely. It should instead maintain its importance for those of the inter- 
national crimes that are usually committed in places where their punishability cannot be always secured. 